\title{
EFEKTIFITAS PENGGUNAAN GOOGLE CLASSROOM DALAM PEMBELAJARAN JARAK JAUH MATA PELAJARAN PAI DAN BUDI PEKERTI DI MASA PANDEMI COVID-19
}

\author{
SRI INDARWATI \\ SMA Negeri 1 Candiroto Temanggung \\ Email : sindarwati46@gmail.com
}

\begin{abstract}
ABSTRAK
Mata Pelajaran Pendidikan Agama Islam dan Budi Pekerti menjadi salah satu bagian dari kurikulum yang telah ditetapkan. Di masa sekarang ini, yaitu masa pandemi covid-19 menuntut kita untuk melakukan pembelajaran jarak jauh (PJJ). Namun permaslahannya tidak semua pelajar aktif mengikuti pembelajaran. Google Classroom adalah salah satu media pembelajaran yang bisa digunakan untuk mengaktifkan siswa dalam mengikuti pembelajaran jarak jauh. Tujuan penelitian ini adalah untuk melihat sejauh mana Classroom mampu meningkatkan keaktifan siswa dalam mengikuti pembelajaran jarak jauh untuk mata pelajaran PAI dan Budi Pekerti.
\end{abstract}

Kata Kunci: Google classroom, Pembelajaran Jarak Jauh, dan Pandemi Covid-19

\section{PENDAHULUAN}

Karena adanya wabah Covid-19, maka berpengaruh di semua ranah kehidupan manusia, termasuk dunia pendidikan. Pengaruh Covid-19 telah mengubah konsep, método dan desain pembelajaran yang ada. Pembelajaran yang dulunya dilakukan dengan tatap muka antara guru dan siswa, sekarang harus dilakukan dengan pembelajaran jarak jauh. Hal itu sesuai dengan surat edaran Mendikbud RI No 3 Tahun 2020 tentang pencegahan Covid-19 dan surat edaran Mendikbud RI No 4 Tahun 2020 tentang Pelaksanaan Kebijakan Pendidikan dalam Masa Darurat Penyebaran Covid-19 tertanggal 24 Maret 2020, maka seluruh satuan pendidikan termasuk SMA dan SMK, dengan himbauan pemerintah melakukan aktivitas belajar dari rumah atau Pembelajaran Jarak Jauh (PJJ) dengan berbasis online (RI, Lt, \& Subroto, 2020).

Salah satu masalah yang dihadapi Dunia pendidikan pada masa pandemi Covid-19 mengharuskan semua pendidik (guru dan dosen) melakukan tugas-tugas dari rumah ( Marbun, 2021). Maka guru atau pendidik dalam melakukan pembelajaran harus dengan Pembelajaran Jarak Jauh (PJJ). Pembelajaran Jarak Jauh (PJJ) atau yang sering disebut dengan pembelajaran daring merupakan pembelajaran yang berlangsung dalam jaringan dimana pengajar dan yang diajar tidak bertatap muka secara langsung (Albert Efendi, 2020). Pembelajaran daring menuntut kesiapan guru sebagai aktor utama dalam memberikan pembelajaran, kesiapan siswa dalam mengikuti pembelajaran, juga dibutuhkan peran orang tua sebagi pengawas siswa dalam mengikuti pembelajaran daring. Keikutsertaan orang tua sebagai pengawas dalam pembelajaran ini karena anak mengikuti pembelajaran dari rumah. Hal itu disebabkan karena anak memang mengikuti pembelajaran dari rumah masing-masing.

Pembelajaran daring dikenal dengan istilah e-learning. E-Learning merupakan suatu jenis media belajar mengajar yang memungkinkan tersampaikannya bahan ajar ke peserta didik dengan menggunakan media internet, intranet atau media jaringan komputer lain (Muhammad Imanuddin, 2020). E-learning juga merupakan proses pembelajaran berbasis elektronik dalam penggunaannya dapat diakses secara online (Weni dan Isnani, 2016). E-learning ini adalah cara efektif yang digunakan untuk pembelajaran selama masa pandemi covid-19 ini.

Penggunaan Teknologi Informasi (TI) dalam pembelajaran jarak jauh merupakan salah satu alternatif yang dapat digunakan untuk mengatasi solusi dalam pembelajaran di masa pandemi covid - 19 sekarang ini. Menurut Milman (2015) penggunaan teknologi digital memungkinkan siswa dan guru verada di tempat yang berbeda selama proses pembelajaran. Berarti dengan menggunakan Teknologi Informasi kita dapat melakukan pembelajaran daring. Banyak platform yang bisa kita gunakan untuk penyampaian materi pembelajaran . Salah 
satunya adalah google classroom. Dan google classroom merupakan salah satu platform yang digunakan untuk pembelajaran daring di SMA Negeri 1 Candiroto Temanggung.

Google classroom adalah layanan web gratis, yang dikembangkan oleh google untuk sekolah, yang bertujuan untuk menyederhanakan, membuat, mendistribusikan, dan menilai tugas tanpa tatap muka. Tujuan utama google classroom adalah untuk merampingkan proses berbagi file antara guru dan siswa. google classroom dapat digunakan untuk mengirim materi baik berupa modul, PPT, video dan yang lainnya. Selain itu juga langsung dapat digunakan untuk presensi siswa dan tugas siswa. Tugas siswapun dapat juga berupa google form, yang langsung dapat dilihat nilainya, tugas portofolio, atau tugas yang lain.

\section{METODE PELAKSANAAN}

Penulis memilih media google clasroom sebagai media pembelajaran jarak jauh pada mapel PAI dengan pertimbangan utama bahwa pada classroom dapat mempermudah interaksi seorang pendidik dengan peserta didik dalam dunia internet. Google classroom memberikan kemudahan kepada seorang pendidik mengeksplor materi dan yang lainnya kepada peserta didik. Dan dalam praktiknya, Google classroom sangat mudah digunakan dalam kegiatan pembelajaran jarak jauh. Maka Google classroom sebagai salah satu media yang perlu dicoba dan dimaksimalkan dalam pembelajaran PAI dan Budi Pekerti.

Best practice dilakukan pada semester genap Tahun Pelajaran 2020/2021 di kelas XII MIPA 2 dengan menggunakan google classroom untuk pembelajran jarak jauh. Sebelumnya, di awal pandemi Covid-19 penulis menggunakan Whash App group dalam pembelajaran online. Tetapi mengalami kesulitan dalam presensi, pengecekan pengumpulan tugas siswa, dan penyimpanan berkas pengumpulan tugas di HP cepat penuh, sehingga HP lemot pada waktu digunakan dan juga cepat rusak. Selain itu keaktifan siswa dalam mengikuti pembelajaran tidak maksimal. Banyak siswa yang terlambat presensinya, bahkan tidak mengikuti pembelajaran. Kadang ada anak yang mengikuti pembelajaran, tetapi tidak mengumpulkan tugas yang diberikan. Maka di semester genap beralih menggunakan aplikasi google classroom. Dengan menggunakan aplikasi google classroom, semua siswa dalam satu kelas itu harus masuk dalam aplikasi itu, dan masing masing siswa dapat mengecek sendiri presensi atau keikutsertaan dalam pembelajaran dan mengecek ugas-tugas yang belum maupun sudah dikumpulkan, sehingga siswa yang kurang aktif dalam pembelajaran dan tidak mengumpulkan tugas akan malu sendiri. Dengan demikian, dengan aplikasi Google classroom siswa semakin aktif dalam mengikuti pembelajaran dan bertambah aktif dalam mengumpulkan tugas di semester genapnya.

\section{PEMBAHASAN DAN HASIL}

Penulis akan memaparkan análisis pelaksanaan pembelajaran dengan google classroom di era pandemi Covid-19 di SMA Negeri I Candiroto Temanggung Tahun Pelajaran 2020/2021.

\section{Proses Pembelajaran di era Pandemi Covid-19}

Di masa pandemi Covid-19, kegiatan pembelajaran harus tetap berjalan. Pelaksanaan pembelajaran di era pandemi Covid-19 tidak jauh berbeda dengan pembelajaran tatap muka di sekolah. Pendidik tetapharus berinteraksi dengan peserta didik walaupun dengan pembelajaran jarak jauh atau pembelajaran online. Walaupun pembelajaran online, tetapi rangkaian pembelajaran sama seperti pembelajaran tatap muka yang pelaksanaannya meliputi kegiatan pendahuluan, kegiatan inti dan kegiatan penutup. Metode yang dapat digunakan antara lain dengan Whash App (WA) group, google classroom, google drive, google sway dan sebagainya. Metode-metode pembelajaran itu dapat dilaksanakan dengan menggunakan media HP Android, komputer atau laptop yang dimiliki oleh siswa dengan jaringan internet yang memadai.

\section{Hakekat Metode Pembelajaran PAI dan Budi Pekerti dengan Google Classroom}

Mata pelajaran PAI dan Budi Pekerti adalah mata pelajaran yang wajib ada di Sekolah Menengah Atas (SMA). Pembelajan PAI dan Budi Pekerti yang di dalamnya ada materi pembahasan tentang akhlak dapat membentuk siswa yang mempunyai akhlak yang baik atau 
berakhlakul karimah. Pemilihan metode yang tepat dalam pembelajran PAI dan Budi Pekerti merupakan salah satu indikator ketercapaian dalam suatu pembelajaran.

Materi pembelajan PAI dan Budi Pekerti di sekolah mencakup lima aspek. Aspek tersebut antara lain aspek Al Qur'an, aspek Aqidah, aspek akhlak, aspek Fiqih dan aspek Tarekh atau sejarah kebudayaan Islam. Dalam struktur kurikulum, jumlah jam mata pelajaran PAI dan Budi Pekerti di SMA adalah 3 Jam Pelajaran (JP) dalam setiap minggunya.Untuk mencapai indikator pembelajaran, maka seorang pendidik harus mempunyai strategi pembelajaran agar dapat mendorong aktivitas siswa dalam belajar PAI dan Budi Pekerti.

Google classroom adalah salah satu métode yang dirancang untuk mempermudah proses pembelajaran jarak jauh supaya seorang pendidik dapat berinteraksi dengan peserta didik. Aplikasi ini diciptakan oleh google yang dengan kecanggihannya dapat membuat ruang kelas tanpa dengan proses tatap muka. Siswa yang tergabung dalam kelas aplikasi ini dapat melihat materi yang diberikan oleh guru, melakukan presensi, mengumpulkan tugas yang diberikan guru, bahkan dapat mengecek ugas-tugas yang telah dikumpulkan. Dengan aplikasi ini, guru mempunyai waktu atau kesempatan yang lebih dalam menyampaikan materi dan memberikan tugas-tugas kepada peserta didik. Dengan aplikasi ini juga, guru memberi kesempatan kepada peserta didik supaya terbiasa dengan teknologi (IT).

Menggunakan google classroom dapat mengintegrasikan aplikasi youtube dan google drive ke dalam google classroom, sehingga memudahkan bagi pengguna classroom ini dalam mengelola dokumen video pembelajaran ataupun dokumen pembelajaran yang lainnya dengan ukuran file yang besar. Maka media google classroom ini dapat dicoba dan digunakan dalam pembelajaran PAI dan Budi Pekerti.

Menggunakan google classroom membutuhkan kemampuan khusus dalam bidang Teknologi dan Komunikasi (TIK). Guru yang mahir dalam bidang TIK tentu sangat mudah menggunakan aplikasi ini.

\section{Langkah-langkah mengoperasikan Google classroom}

Mengoperasikan google classroom bagi guru bukanlah suatu hal yang sulit. Tetapi tetap harus mempunyai kemampuan dalam bidang TIK. Langkah-langkah dalam mengoperasikan google classroom sebagai berikut :

a. Buka Mozilla Firefox atau Google Chrome, ketik google classroom dan enter.

b. Guru membuat kelas sebanyak kelas yang diampu, dan diberi nama masing-masing kelas

c. Guru mengundang siswa dengan membagikan link atau kode kelas dari kelas di google classroom melalui WA group kelas.

d. Setelah semua siswa masuk ke classroom, kita buka kelas yang akan kita ajar, diatas tertulis fórum yang isinya adalah semua anggota yang ada di kelas itu, baik kita sebagai guru maupun semua siswa yang ada di kelas itu, tugas kelas yang nantinya dapat kita gunakan untuk mengirimkan materi pembelajaran yang akan kita sampaikan, mengabsen siswa, memberikan tugas siswa baik secara individu maupun kelompok.

e. Ketika ada jam pembelajaran, guru menyisipkan materi. Materi yang disisipkan dapat berupa video, youtube, modul, atau PPT.

f. Guru memberikan tugas mandiri dengan menekan tambah dan klik untuk tugas, lalu menuliskan tugas yang akan diberikan. Siswa dapat melihat setiap tugas yang diberikan oleh guru, dan dapat juga melihat batas waktu pengumpulan tugas itu. Dengan memberikan tugas mandiri kepada siswa ini, guru bisa melihat dengan cepat siapa saja siswa yang telah mengumpulkan tugas yang diberikan oleh guru. Dan guru bisa memberikan komentar kepada siswa mengenai pekerjaan siswa yang telah dikumpulkan tersebut.

g. Guru juga dapat meakukan presensi dengan klik tambah, lalu klik di pertanyaan yang nantinya mudah untuk dilihat dengan menggunakan pilihan ganda diklik, kemudian ditulis kata hadir, yang nantinya anak-anak hanya klik di kata hadir itu maka itu sudah terekam sebagai presensi siswa yang mengikuti pembelajaran. 
h. Untuk Penilaian Harian Untuk penilaian hariankita juga bisa memasukkan ke google classroom dengan klik tambah kemudian klik di bagian tugas kuis. Setelah itu kita bisa memasukkan google drive yang sudah kita siapkan dengan memasukkan link, atau kita bisa langsung membuat atau mengetik penilaian harian langsung disitu.

i. Untuk tempat diskusi Google classroom juga dapat digunakan sebagai tempat diskusi antara siswa dan guru. Siswa dapat bertanya kepada guru mengenai materi yang dibahas yang belum dipahami oleh siswa. Misalnya pada pembahasan tentang tajwid,siswa dapat bertanya dengan guru tentang hukum bacaan atau tajwid dari ayat yang sedang dibahas, dan guru menjelaskannya dalam fórum tanya jawab atau diskusi. Misalnya juga diskusi tentang permasalahan yang berhubungan dengan materi pembelajaran.

j. Untuk tatap muka antara guru dan siswa lewat meet.

Di google classroom juga tersedia konten google meet yang dapat digunakan untuk ajang tatap muka antara guru dan siswa. Google meet biasanya digunakan pada awal pembelajaran untuk menyapa para siswa dalam pendahuluan dan juga bisa digunakan sebagai presensi dalam pembelajaran. Selain itu, juga dapat digunakan dalam menjelaskan materi yang memang memerlukan penjelasan secara langsung. Misalnya dalam mata pelajaran yang memerlukan penjelasan adalah tentang tajwid atau hukum bacaan Al Qur'an, tentang penghitungan pembagian harta warisan dan lain-lain yang sulit untuk dipahami.

\section{Kelebihan dan Kekurangan Google Classroom}

Google classroom mempunyai kelebihan-kelebihan, diantaranya :

a. Mudah dan gratis

Aplikasi ini sangat mudah diakses melalui play store ataupun google play. Selain mudah diakses, aplikasi ini juga gratis.

b. Proses pengaturannya cepat.

Kecanggihan yang dimiliki oleh google classroom memungkinkan proses pengaturan dengan cepat. Dengan aplikasi google classroom, guru lebih mudah mengaksesnya dan memulai pembelajaran dengan membagikan materi dan membagikan tugas-tugas kepada peserta didik. Sehingga google classroom ini mudah digunakan dengan proses pengaturan yang cepat.

c. Penyimpanan data terpusat.

Dengan aplikasi ini semua data, dokumen tugas yang diberikan oleh guru, serta dokumen pengumpulan tugas oleh siswa tersimpan dengan baik di tempat yang sudah tersedia. Materi pembelajaran dan data nilai juga dapat tersimpan di aplikasi ini. Jadi, semua data baik dari guru maupun dari siswa tersimpan dengan baik di dalam aplikasi google classroom ini.

d. Hemat ruang dan waktu.

Dengan aplikasi ini, guru lebih mudah memberikan tugas kepada para siswa dan siswa dengan mudah juga mengetahui tugas-tugas yang diberikan oleh guru kapanpun dan dimanapun siswa dan guru itu berada. Sehingga dapat dikatakan bahwa aplikasi ini hemat ruang dan waktu. guru juga bisa menilai dengan cepat tugas siswa yang telah diserahkan oleh siswa.

e. Terjangkau, aman, dan nyaman.

Karena aplikasi ini gratis, para guru dan siswa dapat menjangkau aplikasi ini tanpa mengeluarkan biaya. Hanya dengan modal data internet atau wifi saja aplikasi ini dapat diakses. Aplikasi ini juga menjamin tingkat keamanan bagi siapa saja yang masuk ke aplikasi ini, karena aplikasi ini sudah diatur sedemikian rupa oleh google selama kata kunci hanya diketahui oleh pemiliknya. Dan aplikasi ini nyaman digunakan dimana semua siswa yang tergabung dalam classroom dapat berkomunikasi langsung kepada guru.

f. Meningkatkan disiplin para siswa.

Dengan google classroom ini, siswa dapat lebih disiplin dalam belajar, karena ada aturan yang diberikan oleh guru selama pembelajaran. Penyerahan presensi siswa diberi tenggat waktu. Begitu pula untuk pengumpulan tugas siswa juga diberi tenggat waktu, sehingga pembelajaran dengan google classroom ini dapat meningkatkan disiplin siswa. 
g. Meningkatkan kerjasama dan komunikasi kelas.

Dengan aplikasi ini, guru dan siswa dapat berkomunikasi misalnya dalam pendahuluan pembelajaran. Guru dan siswa dapat bertegur sapa walaupun dalam jarak yang jauh dan tidak bertatap muka secara langsung seperti ketika di dalam kelas. Guru dan siswa juga dapat melakukan diskusi melalui aplikasi ini. Sehingga aplikasi ini dapat meningkatkan kerjasama dan komunikasi kelas.

Selain mempunyai kelebihan-kelebihan, aplikasi ini juga mempunyai kelemahan bagi penggunanya. Karena secanggih apapun produk yang dikembangkan untuk proses belajar mengajar atau pembelajaran, pasti ada kekurangan-kekurangannya.

Kekurangan aplikasi google classroom antara lain :

a. Hanya dapat diakses dengan jaringan atau internet.

Aplikasi ini hanya dapat dibuka dan diakses ketika ada jaringan. Jadi kebutuhan wifi di sekolah mutlak diperlukan ketika menggunakan aplikasi ini. Jika jaringan wifi di sekolah buruk, maka tidak dapat menggunakan aplikasi ini. Ketika siswa belajar di rumah, jaringan wifi atau paket data internet juga sangat dibutuhkan. Jika paket data siswa tidak ada, maka siswa juga tidak dapat melihat meteri pembelajaran dan tugas yang diberikan oleh guru.

b. Tidak adanya notifikasi dari aplikasi ini.

Aplikasi ini tidak memberikan notifikasi peringatan pada akun yang kita miliki. Sehingga, siswa harus sering memeriksa dengan membuka aplikasi ini apabila ada tugas dari guru.

\section{Pembahasan Penelitian}

Penggunaan aplikasi ini di kelas XII MIPA 2. Berikut data siswa kelas XII MIPA 2 :

Data kehadiran siswa dalam 5 kali pertemuan sebelum menggunakan google classroom dan masih menggunakan WA group PAI kelas di semester ganjil Tahun Pelajaran 2020/2021, sebagai berikut :

\begin{tabular}{|c|c|c|c|c|c|c|}
\hline 占 & NAMA & $\mathrm{I}$ & II & III & IV & $\mathrm{V}$ \\
\hline 1 & A'IDA HUSNA USTAFIA & $\mathrm{V}$ & $\mathrm{V}$ & - & $\mathrm{V}$ & V \\
\hline 2 & ALIF AULIA NUR AENI & $\mathrm{V}$ & - & $\mathrm{V}$ & - & $\mathrm{V}$ \\
\hline 3 & ALYA NOVITRI ANI & $\mathrm{V}$ & $\mathrm{V}$ & $\mathrm{V}$ & $\mathrm{V}$ & $\mathrm{V}$ \\
\hline 4 & AMIE NASIFAH & $\mathrm{V}$ & $\mathrm{V}$ & $\mathrm{V}$ & $\mathrm{V}$ & $\mathrm{V}$ \\
\hline 5 & AMRI SELFIA & $\mathrm{V}$ & $\mathrm{V}$ & $\mathrm{V}$ & $\mathrm{V}$ & $\mathrm{V}$ \\
\hline 6 & $\begin{array}{cc}\text { ARIFA } & \text { FARRAS } \\
\text { FADHILA } & \\
\end{array}$ & $\mathrm{V}$ & $\mathrm{V}$ & $\mathrm{V}$ & - & $\mathrm{V}$ \\
\hline 7 & $\begin{array}{cc}\text { BIMA } & \text { AKBAR } \\
\text { MAULANA }\end{array}$ & - & - & - & V & - \\
\hline 8 & $\begin{array}{cc}\text { CINDY } & \text { TUNJUNG } \\
\text { SAFRIANDINI } & \end{array}$ & $\mathrm{V}$ & $\mathrm{V}$ & V & - & V \\
\hline 9 & DEVA MUKHOLIFAH & $\mathrm{V}$ & $\mathrm{V}$ & $\mathrm{V}$ & $\mathrm{V}$ & $\mathrm{V}$ \\
\hline 10 & DIAN RAHMAWATI & - & $\mathrm{V}$ & $\mathrm{V}$ & - & - \\
\hline 11 & $\begin{array}{l}\text { DYAH AYU KUSUMA } \\
\text { PENGGING }\end{array}$ & $\mathrm{V}$ & $\mathrm{V}$ & $\mathrm{V}$ & - & V \\
\hline 12 & FATKHUL ANAM & - & $\mathrm{V}$ & $\mathrm{V}$ & $\mathrm{V}$ & $\mathrm{V}$ \\
\hline 13 & FERI OKTABRIAN & - & - & $\mathrm{V}$ & $\mathrm{V}$ & $\mathrm{V}$ \\
\hline 14 & GALIH ARDIANSYAH & $\mathrm{V}$ & - & $\mathrm{V}$ & - & - \\
\hline 15 & IMELDA VIOLITA & $\mathrm{V}$ & $\mathrm{V}$ & $\mathrm{V}$ & - & $\mathrm{V}$ \\
\hline 16 & KHANIN NAIMA & $\mathrm{V}$ & $\mathrm{V}$ & $\mathrm{V}$ & $\mathrm{V}$ & $\mathrm{V}$ \\
\hline
\end{tabular}




\begin{tabular}{|c|c|c|c|c|c|c|}
\hline 17 & $\begin{array}{c}\text { LARAS } \\
\text { RICADONA }\end{array}$ & - & V & V & V & $\mathrm{V}$ \\
\hline 18 & LEBBY AL ALIFI & V & V & V & $\mathrm{V}$ & $\mathrm{V}$ \\
\hline 19 & LILIAN DEA PRIANDINI & V & - & V & V & V \\
\hline 20 & LILIS AGUSTIN & $\mathrm{V}$ & $\mathrm{V}$ & $\mathrm{V}$ & $\mathrm{V}$ & $\mathrm{V}$ \\
\hline 21 & $\begin{array}{ll}\text { MESFANEVA } & \text { RISQI } \\
\text { MAHARDIKA } & \\
\end{array}$ & - & - & - & V & - \\
\hline 22 & $\begin{array}{ll}\text { MIFTACHUL } & \text { ILMIA } \\
\text { WACHDAH } & \end{array}$ & V & V & V & V & V \\
\hline 23 & $\begin{array}{cc}\text { MILAM } & \text { OKTAPI } \\
\text { PURWO PUTRI } & \end{array}$ & - & - & V & V & V \\
\hline 24 & $\begin{aligned} \text { MUHAMMAD } & \text { REVRI } \\
\text { BAGUS SAJIWO } & \end{aligned}$ & - & - & - & V & $\mathrm{V}$ \\
\hline 25 & MUSLICHATUN & V & V & V & - & $\mathrm{V}$ \\
\hline 26 & NUR'AENI & $\mathrm{V}$ & $\mathrm{V}$ & V & V & $\mathrm{V}$ \\
\hline 27 & $\begin{array}{cc}\text { PUTRI } & \text { ALFIATUL } \\
\text { MUNIFAH } & \end{array}$ & $\mathrm{V}$ & V & V & V & V \\
\hline 28 & $\begin{array}{l}\text { RAFSAN } \\
\text { KUROMA }\end{array}$ & - & - & V & - & - \\
\hline 29 & RAHMA HERMAWANTI & $\mathrm{V}$ & V & V & $\mathrm{V}$ & $\mathrm{V}$ \\
\hline 30 & $\begin{array}{r}\text { RINASTITI } \\
\text { ANGGRAENI }\end{array}$ & $\mathrm{V}$ & V & V & - & $\mathrm{V}$ \\
\hline 31 & $\begin{array}{cc}\text { RIZJKI } & \text { WAHYU } \\
\text { HANANTO } & \\
\end{array}$ & - & $\mathrm{V}$ & - & V & V \\
\hline 32 & SANTI SEFIRA & $\mathrm{V}$ & $\mathrm{V}$ & $\mathrm{V}$ & $\mathrm{V}$ & $\mathrm{V}$ \\
\hline 33 & $\begin{array}{ll}\text { TANDIKA } & \text { AXSA } \\
\text { PRASETYO } & \\
\end{array}$ & V & - & V & - & V \\
\hline 34 & ZULFA KHARISTA & V & V & $\mathrm{V}$ & $\mathrm{V}$ & $\mathrm{V}$ \\
\hline
\end{tabular}

Dari tabel diatas dapat dilihat pada pertemuan pertama yang mengikuti pembelajaran hanya 24 orang, di pertemuan kedua juga 24 orang, di pertemuan ketiga 29 orang, di pertemuan keempat hanya 23 siswa dan di pertemuan kelima 29 orang.

Data kehadiran siswa dalam 5 kali pertemuan setelah menggunakan google classroom di semester genap Tahun Pelajaran 2020/2021 sebagai berikut :

\begin{tabular}{|c|c|c|c|c|c|c|}
\hline 占 & NAMA & $\mathrm{I}$ & II & III & IV & V \\
\hline 1 & A'IDA HUSNA USTAFIA & V & $\mathrm{V}$ & $\mathrm{V}$ & $\mathrm{V}$ & $\mathrm{V}$ \\
\hline 2 & ALIF AULIA NUR AENI & $\mathrm{V}$ & V & $\mathrm{V}$ & $\mathrm{V}$ & $\mathrm{V}$ \\
\hline 3 & ALYA NOVITRI ANI & $\mathrm{V}$ & $\mathrm{V}$ & $\mathrm{V}$ & $\mathrm{V}$ & $\mathrm{V}$ \\
\hline 4 & AMIE NASIFAH & V & V & $\mathrm{V}$ & $\mathrm{V}$ & $\mathrm{V}$ \\
\hline 5 & AMRI SELFIA & $\mathrm{V}$ & $\mathrm{V}$ & $\mathrm{V}$ & $\mathrm{V}$ & $\mathrm{V}$ \\
\hline 6 & $\begin{array}{c}\text { ARIFA } \\
\text { FADHILA }\end{array}$ & $\mathrm{V}$ & V & V & V & $\mathrm{V}$ \\
\hline 7 & $\begin{array}{c}\text { BIMA } \\
\text { MAULANA }\end{array}$ & - & V & - & V & V \\
\hline 8 & $\begin{array}{cc}\text { CINDY } & \text { TUNJUNG } \\
\text { SAFRIANDINI } & \\
\end{array}$ & V & V & V & $\mathrm{V}$ & V \\
\hline
\end{tabular}




\begin{tabular}{|c|c|c|c|c|c|c|}
\hline 9 & DEVA MUKHOLIFAH & $\mathrm{V}$ & V & V & V & V \\
\hline 10 & DIAN RAHMAWATI & $\mathrm{V}$ & $\mathrm{V}$ & $\mathrm{V}$ & V & $\mathrm{V}$ \\
\hline 11 & $\begin{array}{l}\text { DYAH AYU KUSUMA } \\
\text { PENGGING }\end{array}$ & V & V & V & V & V \\
\hline 12 & FATKHUL ANAM & $\mathrm{V}$ & $\mathrm{V}$ & $\mathrm{V}$ & $\mathrm{V}$ & $\mathrm{V}$ \\
\hline 13 & FERI OKTABRIAN & - & - & V & $\mathrm{V}$ & $\mathrm{V}$ \\
\hline 14 & GALIH ARDIANSYAH & $\mathrm{V}$ & V & V & $\mathrm{V}$ & V \\
\hline 15 & IMELDA VIOLITA & $\mathrm{V}$ & $\mathrm{V}$ & $\mathrm{V}$ & $\mathrm{V}$ & $\mathrm{V}$ \\
\hline 16 & KHANIN NAIMA & $\mathrm{V}$ & V & $\mathrm{V}$ & V & $\mathrm{V}$ \\
\hline 17 & $\begin{array}{c}\text { LARAS } \\
\text { RICADONA }\end{array}$ & - & V & V & V & $\mathrm{V}$ \\
\hline 18 & LEBBY AL ALIFI & $\mathrm{V}$ & V & V & V & $\mathrm{V}$ \\
\hline 19 & LILIAN DEA PRIANDINI & $\mathrm{V}$ & $\mathrm{V}$ & $\mathrm{V}$ & $\mathrm{V}$ & $\mathrm{V}$ \\
\hline 20 & LILIS AGUSTIN & $\mathrm{V}$ & V & V & V & V \\
\hline 21 & $\begin{array}{l}\text { MESFANEVA } \\
\text { MAHARDIKA }\end{array}$ & - & - & - & V & V \\
\hline 22 & $\begin{array}{l}\text { MIFTACHUL ILMIA } \\
\text { WACHDAH }\end{array}$ & V & V & V & V & V \\
\hline 23 & $\begin{array}{cc}\text { MILAM } & \text { OKTAPI } \\
\text { PURWO PUTRI } & \\
\end{array}$ & $\mathrm{V}$ & $\mathrm{V}$ & $\mathrm{V}$ & $\mathrm{V}$ & $\mathrm{V}$ \\
\hline 24 & $\begin{aligned} \text { MUHAMMAD } & \text { REVRI } \\
\text { BAGUS SAJIWO } & \end{aligned}$ & - & - & - & V & $\mathrm{V}$ \\
\hline 25 & MUSLICHATUN & $\mathrm{V}$ & V & V & V & $\mathrm{V}$ \\
\hline 26 & NUR'AENI & V & V & V & V & V \\
\hline 27 & $\begin{array}{c}\text { PUTRI } \\
\text { MUNIFAH }\end{array}$ & $\mathrm{V}$ & V & V & V & V \\
\hline 28 & $\begin{array}{l}\text { RAFSAN } \\
\text { KUROMA }\end{array}$ & - & - & V & V & V \\
\hline 29 & RAHMA HERMAWANTI & $\mathrm{V}$ & $\mathrm{V}$ & $\mathrm{V}$ & V & $\mathrm{V}$ \\
\hline 30 & $\begin{aligned} & \text { RINASTITI } \text { DWI } \\
& \text { ANGGRAENI } \\
&\end{aligned}$ & $\mathrm{V}$ & V & $\mathrm{V}$ & $\mathrm{V}$ & $\mathrm{V}$ \\
\hline 31 & $\begin{array}{cc}\text { RIZJKI } & \text { WAHYU } \\
\text { HANANTO } & \\
\end{array}$ & - & V & V & V & V \\
\hline 32 & SANTI SEFIRA & V & V & V & V & $\mathrm{V}$ \\
\hline 33 & $\begin{array}{ll}\text { TANDIKA } & \text { AXSA } \\
\text { PRASETYO } & \\
\end{array}$ & $\mathrm{V}$ & V & V & V & V \\
\hline 34 & ZULFA KHARISTA & $\mathrm{V}$ & $\mathrm{V}$ & $\mathrm{V}$ & $\mathrm{V}$ & $\mathrm{V}$ \\
\hline
\end{tabular}

Dari tabel kehadiran di semester genap dari pertemuan pertama yang ikut pembelajarn online sebanyak 27 orang, di pertemuan kedua yang ikut pembelajaran sebanyak 30 siswa, di pertemuan ketiga yang ikut pembelajaran sebanyak 31 siswa, dan di pertemuan keempat dan kelima yang iku pembelajaran sebanyak 34 siswa yang artinya di pertemuan keempat dan kelima sudah ikut pembelajaran semua.

Dari penjelasan diatas kehadiran siswa dalam mengikuti pembelajaran online semakin meningkat dari pertemuan pertama ke pertemuan-pertemuan selanjutnya.

Dengan melihat tabel perbandingan di semester ganjil dan semester genap tersebut, maka di semester genap dengan menggunakan aplikasi google classroom termasuk best practice. 


\section{KESIMPULAN}

Pembelajaran Jarak Jauh dilaksanakan karena himbauan dari pemerintah untuk mencegah wabah Covid-19. Dalam melaksanakan pembelajaran jarak jauh, guru harus dapat memilih strategi yang tepat agar pembelajaran dapat terlaksana dengan baik. Google classroom merupakan métode yang mudah dan tepat untuk PJJ atau pembelajaran online. Banyak kelebihan-kelebihan dari aplikasi google classroom, sehingga aplikasi ini dapat digunakan oleh guru untuk Pembelajaran Jarak Jauh (PJJ).

Pembelajaran PAI dan Budi Pekerti di SMA Negeri 1 Candiroto Temanggung dengan menggunakn google classroom dapat meningkatkan aktivitas belajar siswa selama pembelajaran online. Setelah dianalis dan dievaluasi, penggunaan aplikasi google classroom dapat meningkatkan keaktifan siswa dalam Pembelajaran Jarak Jauh atau pembelajaran online.

\section{DAFTAR PUSTAKA}

Marbun, Purim. (2021). Desain Pembelajaran Online Pada Era Dan Pasca Covid-19. Csrid (Computer Science Research And Its Development Journal), 12(2), 129-142.

Mufron, Ali. (2013). Ilmu Pendidikan Islam. Yogyakarta. Aura Pustaka.

Ri, B. K. D., Lt, Gd Nusantara I., \& Subroto, Jl Jend Gatot. (2020). Tantangan Pelaksanaan Kebijakan Belajar Dari Rumah Dalam Masa Darurat Covid-19.

Rozak, Abdul dan Albantaini, Azkia Muharrom. (2018). Desain Perkuliahan Bahasa Arab Melalui Google Classroom, Vol 5 No.1.

Sabran dan Edy Sabara. Keefektifan Google Classroom sebagai Media Pembelajaran, Fakultas Teknik Universitas Negeri Makassar, diakses pada tanggal 26 Nov 2020

Sulistyorini. (2012). Meretas Pendidikan Berkualitas Dalam Pendidikan Islam, Teras. 